WARSZTATY Z GEOGRAFII TURYZMU

ISBN 978-83-7969-138-8 $\quad$ s. 19-33

http://dx.doi.org/10.18778/7969-138-8.03

Mariusz MIEDZIŃSKI

Akademia Pomorska w Słupsku

\title{
MODYFIKACJA CYKLU ŻYCIA OBSZARU TURYSTYCZNEGO (TALC) POPRZEZ WPROWADZENIE ZAŁOŻEŃ TEORII PROGOWEJ NA BAZIE PRZESTRZENI TURYSTYCZNEJ KOŁOBRZEGU
}

\section{Wstęp}

Rok 1990 był początkiem przemian funkcjonalnych i własnościowych turystycznej bazy noclegowej całego polskiego wybrzeża. W ciągu kilku lat część bazy noclegowej ośrodków wypoczynkowych, kolonijnych i zakładów pracy zakończyła swoją działalność. Na ich miejscu powstawały zupełnie nowe obiekty noclegowe przystosowane do działalności całorocznej. Przebieg i kierunki procesu prywatyzacji, jakie miały miejsce w latach 90 . XX w. stanowiły istotny czynnik decydujący o późniejszym rozwoju miejscowości turystycznych polskiego wybrzeża. Część miejscowości nadmorskich dysponowała możliwościami samodzielnego rozwoju funkcji turystycznych, a zjawisko takie można określić mianem rozwoju wewnętrznego (endogenicznego) kapitału ekonomicznego miejscowości turystycznych. Początek lat 90. był okresem rozpoczęcia realizacji wielkiej liczby inwestycji $w$ formie tzw. prywatnych kwater, pensjonatów, pokoi gościnnych wzdłuż całego wybrzeża. Pierwsze nowe duże obiekty noclegowe na polskim wybrzeżu zaczęły powstawać już po 1990 r. jednak większość zbudowano dopiero po $2000 \mathrm{r}$. Rozpoczęto także modernizację i rozbudowę największych obiektów tury- 
stycznych i uzdrowiskowych, w tym tak dużych, jak licząca 1000-1200 łóżek Arka w Kołobrzegu (MIEDZIŃSKI 2009). Największy wzrost wielkości bazy noclegowej przypadał na lata 2005-2009, podczas hossy inwestycyjnej po akcesji w struktury UE (MIEDZIŃSKI 2011). Procesy rozwoju bazy noclegowej zostały wyhamowane w drugiej połowie 2007 r., gdy wybuchł największy kryzys gospodarczy od czasów Wielkiej Depresji lat 1929-1932. Rozwój gospodarczy w Polsce w latach 2007-2013 cechowało wystąpienie faz dwukrotnego spowolnienia i dwukrotnego przyśpieszenia rozwoju gospodarczego. W okresie wieloletnim w skali regionalnej lub lokalnej istotnymi wskaźnikami koniunktury w gospodarce obszarów turystycznych są zmiany wielkości bazy noclegowej oraz wskaźniki wielkości odnotowywanego ruchu turystycznego. Ważną rolę dla określenia fazy rozwoju turystycznych obszarów nadmorskich odgrywa cykl życia obszaru turystycznego. Zmiany przebiegu cyklu życia obszarów turystycznych mogą być wyznacznikiem pozio$\mathrm{mu}$ rozwoju obszaru turystycznego, a wyjątkowym poligonem doświadczalnym do badań $\mathrm{w}$ tym zakresie $\mathrm{w}$ Polsce jest miasto uzdrowisko Kołobrzeg.

\section{Cykl życia obszaru turystycznego i możliwości jego modyfikacji}

Kluczową metodą badań rozwoju miejscowości i regionów turystycznych jest analiza koncepcji cyklu życia obszaru turystycznego (TALC - Tourist Area Life Cycle) (rys. 1). R.W. Butler opublikował ją w 1980 r. w czasopiśmie „The Canadian Geographer" (BUTLER 1980), a powstała w świetle rozważań teorii peryferii R.W. Christallera, dyfuzji innowacji oraz ekonomicznej teorii cyklu życia produktu (KOWALCZYK 2001). R.W. Butler wyróżnił w niej sześć etapów - stadiów podobnych do cyklu życia produktu: faza eksploracji (odkrycie), faza wprowadzenia (wprowadzenie), faza rozwoju (wzrost), faza konsolidacji (dojrzałość), faza stagnacji (nasycenie) fazy odrodzenia - upadku (upadek - odrodzenie). W późniejszym okresie dzięki wprowadzanym modyfikacjom innych autorów dodano fazę stabilizacji oraz zmian funkcji lub odtworzenia (JOHNSTON 2001) oraz fazy reorientacji oraz stagnacji (AGARVAL 2001).

Analizując klasyczny cykl życia miejscowości turystycznej (rys. 1), a zwłaszcza opracowany na tej podstawie cykl życia obszaru turystycznego 


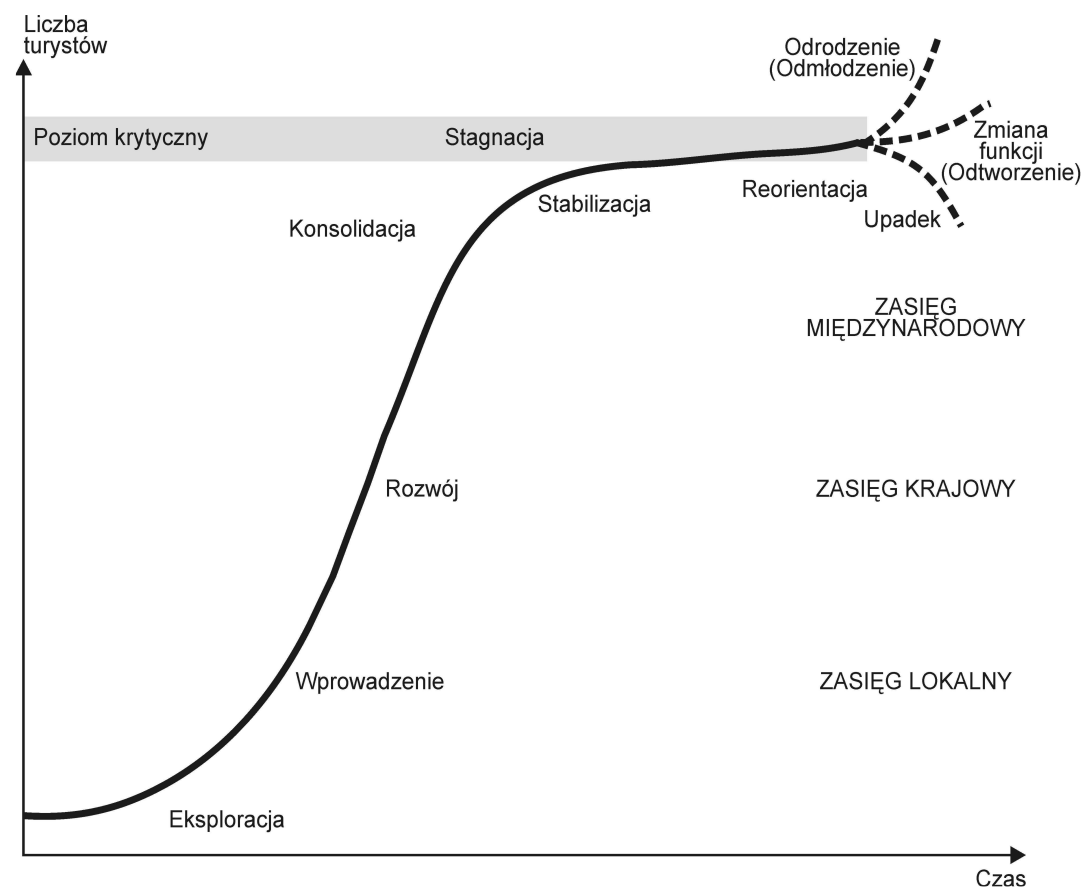

Rys. 1. Klasyczny zmodyfikowany cykl życia obszaru turystycznego według R.W. BUTLERA (2011) z późniejszymi zmianami wprowadzanymi przez innych autorów

Kołobrzegu (na podstawie wielkości bazy noclegowej), należałoby zastanowić się nad tym, jak ten cykl życia faktycznie przebiegał i jaką rangę osiągnął Kołobrzeg w skali kraju (MIEDZIŃSKI 2012) (rys. 2).

Bardzo istotne jest także rozpatrzenie, czy zgodnie z założeniami teorii progowej rozwoju miast możliwe jest przeanalizowanie przypadku ciągłego rozwoju Kołobrzegu (ponad 60 lat) jako wielkiego centrum turystycznego i uzdrowiskowego w kontekście tzw. progów rozwojowych, gdzie funkcja uzdrowiskowa i turystyczna jest dominująca.

Przebieg cyklu życia obszarów (miejscowości) turystycznych (SZROMEK 2010) pozwala zauważyć, że w niektórych przypadkach mamy do czynienia z jednym bardzo długim cyklem życia obszaru (miejscowości turystycznej). Rozwój rejonu turystycznego przebiega etapami (fazami), a etapy takie cechują się przyśpieszeniami rozwoju (impulsami rozwojowymi) w okresie hossy gospodarczej czy spowolnieniem rozwoju (stagnacją rozwoju) podczas recesji lub silnego spowolnienia gospodarczego. Klasyczny jest przypadek chorwackiego uzdrowiska Opatija (Ablacja), w którym wystąpił jeden bar- 
dzo długi cykl Butlera składający się właściwie z trzech mniejszych cykli składowych. Podobnie jak w Kołobrzegu, były tam przerwy w czasie I i II wojny światowej oraz wyraźnie zaznaczający się okres transformacji ustrojowej (intensywnych przemian gospodarczych) (CORAK 2006).

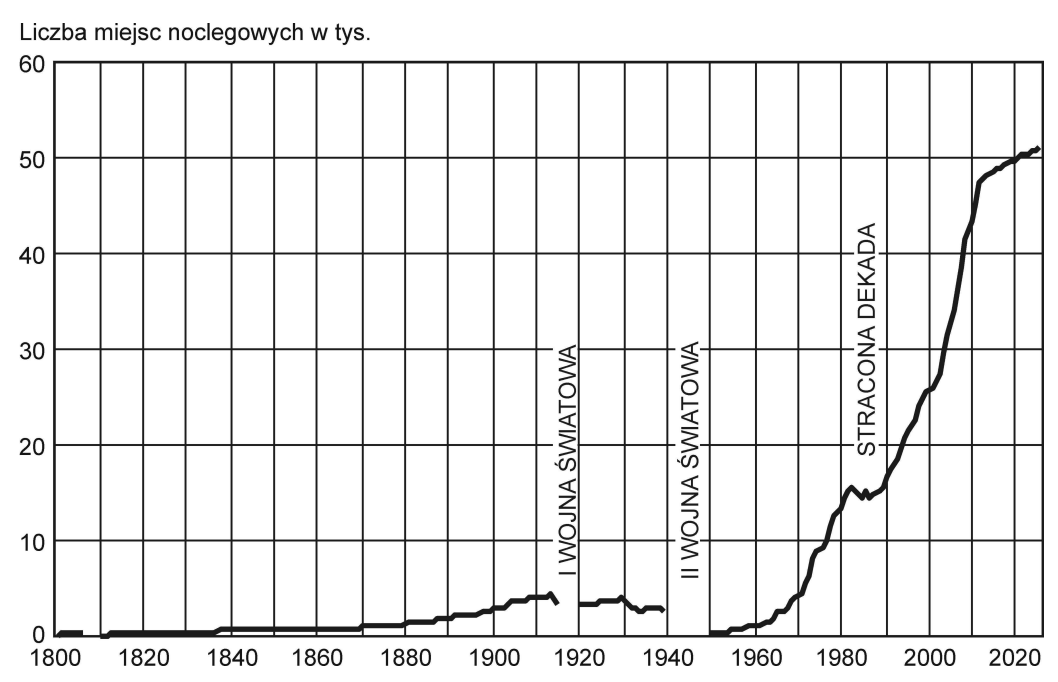

Rys. 2. Zmiany liczby miejsc noclegowych miasta Kołobrzeg w latach 1800-2013 i prognoza do roku 2020 (zmiany liczby miejsc noclegowych obrazują przebieg klasycznego cyklu życia miejscowości turystycznej)

Źródło: badania i opracowanie własne

Z dotychczasowych rozważań wynika, że na terenie miasta Kołobrzeg prawdopodobnie rozpoczął się proces wydłużania przebiegu cyklu życia o kolejny etap wzrostowy, natomiast okres stagnacji (spowolnienia rozwoju) lat 2007-2012 był w Kołobrzegu prawie niezauważalny przebiegając pod znakiem lekkiego spowolnienia rozwoju istniejącej bazy noclegowej przy ciągłym wzroście liczby osobonoclegów. W roku 2012 zakończono kluczową inwestycję poszerzenia plaż i odbudowy brzegów morskich. Plaża centralna w Kołobrzegu na odcinku o długości 3,5 km zwiększyła swoją pojemność turystyczną pięciokrotnie, a jej ogólna pojemność zwiększyła się ponaddwukrotnie. Podniosło to komfort wypoczynku i oddaliło problem przekroczenia chłonności turystycznej oraz zwiększyło pojemność turystyczną obszaru turystycznego. Wbrew ogólnym założeniom R.W. Butlera, tzw. krytyczny poziom pojemności turystycznej może ulec zmianie (podniesieniu) podczas trwania cyklu życia obszaru turystycznego. 


\section{Teoria progowa $w$ rozwoju miast i przestrzeni turystycznych}

Według założeń teorii progowej B. MALISZA (1971) ośrodki miejskie napotykają w swoim rozwoju ludnościowym i przestrzennym na istotne ograniczenia rozwojowe:

- fizyczne (wynikające ze zróżnicowania cech fizjograficznych terenu);

- funkcjonalne (wynikające z układu form użytkowania terenu);

- technologiczne (wynikające z cech układu infrastruktury technicznej);

- strukturalne (wynikające $\mathrm{z}$ konieczności przebudowy struktury terenu).

Każde $\mathrm{z}$ tych ograniczeń może być przekroczone w celu dalszego rozwoju miasta, jednak jest to związane ze znacznymi nakładami finansowymi, a także z podniesieniem kosztów funkcjonowania danego miasta - obszaru miejskiego (koszty rozwoju infrastruktury komunalnej, a w Kołobrzegu dodatkowo koszt rozbudowy plaż i układu komunikacyjnego).

Koszty jednorazowe oraz stałe funkcjonowania i rozwoju miasta są kosztami progowymi, a koszt przekroczenia danego progu nie jest ciągły, lecz odbywa się etapami (skokowo), a skoki te są z kolei wyznaczane przez kluczowe ograniczenia progowe.

Rozwój przestrzenny, ludnościowy albo przyrost substancji mieszkaniowej może odbywać się bez ponoszenia kosztów progowych, jednak będzie to realizowane kosztem jakości i warunków życia mieszkańców oraz powiększenia problemów funkcjonalnych miasta lub obszaru miejskiego poprzez wzrost wskaźników obciążenia i zagęszczenia.

Jednym z mierników pozwalających ustalić, na którym etapie teorii progowej znajduje się analizowane miasto Kołobrzeg może być liczba lokali mieszkalnych (lub izb) oraz skala przyrostu zasobów mieszkaniowych i ich powierzchni użytkowej (KOZŁOWSKI 1974) (tab. 1).

Porównując przyrost liczby ludności (8\%), wzrost liczby mieszkań ogółem (174\%), a zwłaszcza zwiększenie ich powierzchni użytkowej (221\%) w ciągu ostatnich 24 lat można stwierdzić, że Kołobrzeg przekroczył próg rozwojowy wielkości zabudowy mieszkaniowej nie zwiększając przy tym znacząco liczby ludności stałej przy jednoczesnym zwiększeniu potencjalnej pojemności noclegowej miasta wyrażanej w postaci wielu tysięcy funkcjonujących drugich domów i drugich mieszkań. 
Tabela 1. Zasoby mieszkaniowe i ludność miasta Kołobrzeg w latach 1988-2011

\begin{tabular}{|c|c|c|c|c|}
\hline \multirow{2}{*}{ Rok } & \multicolumn{2}{|c|}{ Liczba } & $\begin{array}{c}\text { Powierzchnia użytkowa } \\
\text { mieszkań ogółem }\end{array}$ & $\begin{array}{c}\text { Liczba mieszkańców } \\
\text { ogółem }\end{array}$ \\
\cline { 2 - 3 } & mieszkań & izb & 670063 & 43538 \\
\hline 1988 & 12551 & bd & 800917 & 47301 \\
\hline 1995 & 14469 & 49764 & 815177 & 47480 \\
\hline 1996 & 14623 & 50463 & 823021 & 47886 \\
\hline 1997 & 14685 & 50803 & 833933 & 48082 \\
\hline 1998 & 14787 & 51250 & 847585 & 45029 \\
\hline 1999 & 14927 & 51877 & 863414 & 45107 \\
\hline 2000 & 15065 & 52484 & 887266 & 44995 \\
\hline 2001 & 15356 & 53423 & 1084167 & 44803 \\
\hline 2002 & 17153 & 61862 & 1102515 & 44834 \\
\hline 2003 & 17417 & 62803 & 1119308 & 44932 \\
\hline 2004 & 17682 & 63541 & 1147333 & 44887 \\
\hline 2005 & 18044 & 64492 & 1205703 & 44737 \\
\hline 2006 & 19034 & 66616 & 1235475 & 44889 \\
\hline 2007 & 19387 & 67552 & 1273972 & 44925 \\
\hline 2008 & 19841 & 68588 & 1313295 & 44991 \\
\hline 2009 & 20495 & 70315 & 1445702 & 47103 \\
\hline 2010 & 21275 & 82206 & 1457244 & 47078 \\
\hline 2011 & 21442 & 82659 & 1480514 & 46951 \\
\hline 2012 & 21835 & 83662 & & \\
\hline
\end{tabular}

Źródło: dane statystyczne GUS za lata 1988-2012; opracowanie własne.

Niniejszy próg rozwojowy związany jest z zabudową mieszkaniową i zabudową turystyczno-uzdrowiskową. Ogólna liczba miejsc noclegowych w Kołobrzegu w ciągu ostatnich 23 lat powiększyła się przeszło trzykrotnie (tab. 2).

By mógł nastąpić tak intensywny rozwój turystyczno-uzdrowiskowej bazy noclegowej miasta Kołobrzeg, niezbędne było przekroczenie pierwszego powojennego progu rozwojowego $\mathrm{w}$ formie inwestycji $\mathrm{w}$ infrastrukturę komunalną i techniczną miasta.

Dokonało się to poprzez odbudowę, przebudowę i rozbudowę sieci wodociągowej, kanalizacyjnej, gazowej, energetycznej, telekomunikacyjnej i ciepłowniczej miasta. Zmodernizowane zostało zasilanie miasta w ciepło, zlikwidowano niskoemisyjne źródła zanieczyszczenia powietrza, zmodernizowano i rozbudowano oczyszczalnię ścieków, zbudowano od podstaw stację uzdatniania wody, kompostownię śmieci i przeprowadzono modernizację taboru komunikacji miejskiej. Proces ten zakończył modernizację i wypełnianie dawnej, przedwojennej struktury przestrzennej i infrastrukturalnej miasta. 
MODYFIKACJA CYKLU ŻYCIA OBSZARU TURYSTYCZNEGO (TALC)...

Tabela 2. Zmiany wielkości bazy noclegowej Kołobrzegu w latach 1979-2020

\begin{tabular}{|c|c|c|c|c|c|c|c|}
\hline $\begin{array}{l}\text { Rodzaj obiektów } \\
\text { noclegowych }\end{array}$ & $1979 \mathrm{r}$. & $1989 \mathrm{r}$. & $2010 \mathrm{r}$. & $\begin{array}{l}W \text { bu- } \\
\text { dowie }\end{array}$ & $\begin{array}{c}\text { Do } \\
2015 \mathrm{r} \text {. }\end{array}$ & $\begin{array}{c}\text { Do } \\
2020 \mathrm{r} .\end{array}$ & $\begin{array}{l}\text { Stan w } \\
2020 \mathrm{r}\end{array}$ \\
\hline Pokoje gościnne & 2500 & 3500 & 14027 & 200 & 100 & 200 & 14527 \\
\hline Hotele, motele, pensjonaty & 741 & 741 & 8583 & 530 & 700 & 2300 & 12113 \\
\hline Sanatoria & 5400 & 6129 & 7614 & 750 & 400 & 400 & 9164 \\
\hline $\begin{array}{l}\text { Mieszkania, apartamenty } \\
\text { mieszkalne }\end{array}$ & 300 & 500 & 3886 & 1200 & 500 & 500 & 6086 \\
\hline $\begin{array}{l}\text { Apartamenty w apartamen- } \\
\text { towcach }\end{array}$ & 0 & 0 & 3898 & 375 & 500 & 500 & 5273 \\
\hline $\begin{array}{l}\text { Prywatne miejsca zakwate- } \\
\text { rowania }\end{array}$ & 1000 & 1400 & 3800 & 120 & 250 & 250 & 4420 \\
\hline Ośrodki wczasowe & 4100 & 3025 & 3741 & -150 & -200 & -250 & 3141 \\
\hline $\begin{array}{l}\text { Domy letniskowe, kem- } \\
\text { pingi, pola namiotowe }\end{array}$ & 1000 & 970 & 1573 & 0 & -250 & -250 & 1073 \\
\hline Razem & 15041 & 16265 & 47122 & 3025 & 2000 & 3650 & 55797 \\
\hline
\end{tabular}

Źródło: badania i opracowanie własne oraz H. KROCZYŃSKI (2000) i A. SZWICHTENBERG (1991).

Przekroczenie drugiego progu rozwojowego Kołobrzegu związane było z zagospodarowaniem bardzo rozległych obszarów powojskowych i popoligonowych Kołobrzegu oraz budowy nowych osiedli mieszkaniowych, usługowych i turystyczno-uzdrowiskowych. Przekroczenie pierwszego progu rozwojowego (infrastruktura komunalna i techniczna miasta) pozwoliło na późniejszym etapie na rozpoczęcie przekraczania drugiego progu rozwoju Kołobrzegu dotyczącego budownictwa mieszkaniowego i turystyczno-uzdrowiskowego (nowa zabudowa mieszkaniowa i baza noclegowa w formie bardzo licznych obiektów turystyczno-uzdrowiskowych oraz drugich domów i drugich mieszkań oraz apartamentów). Wieloletni proces przekraczania i pokonanie pierwszego progu rozwojowego przez miasto pozwoliło w konsekwencji na rozpoczęcie przygotowań do przekroczenia tzw. drugiego progu rozwojowego związanego z kompleksową przebudową i rozbudową układu komunikacyjnego miasta i jego bliskiego zaplecza (droga dojazdowa do portu morskiego - etapy I, II, III, jako tzw. obwodnica śródmiejska, łącznie z projektowaną drugą obwodnicą Kołobrzegu w ciągu przygotowywanej do realizacji drogi ekspresowej S-6 relacji Szczecin-Gdańsk w wariancie piątym, zwanym „kołobrzeskim”).

W ramach przekraczania drugiego progu rozwojowego Kołobrzegu obok inwestycji komunikacyjnych ukończono lub realizowane są obiekty usługowe o randze ponadpowiatowej lub regionalnej (Regionalne Centrum Spor- 
tu i Regionalne Centrum Kultury, modernizacja Szpitala Regionalnego, rozbudowa Mariny Kołobrzeg, rozpoczęcie budowy dwu galerii handlowych, od września 2012 r. działa sezonowe lotnisko sportowo-turystyczne. Realizowane są także inwestycje związane $\mathrm{z}$ rozwojem portu handlowego, rybackiego i pasażerskiego, w tym połączeń promowych) (MIEDZIŃSKI 2013a).

$\mathrm{W}$ niedalekiej przyszłości $\mathrm{w}$ ramach przekraczania trzeciego progu rozwojowego Kołobrzegu, obok wielkich inwestycji drogowych (drogi ekspresowe S-6 i S-11), należy uwzględnić przewidywaną zmianę granic administracyjnych miasta, zakładającą wchłonięcie kilku miejscowości wokół niego, a tym samym przekroczenie przez Kołobrzeg liczby 50 tys. stałych mieszkańców) (MIEDZIŃSKI 2013b). Istotne jest także utworzenie Kołobrzeskiego Subregionalnego Obszaru Funkcjonalnego (KSOF) w ramach północnej części powiatu kołobrzeskiego (miasto i gmina Kołobrzeg oraz gmina Ustronie Morskie), gdzie głównym czynnikiem delimitacji KSOF są funkcje turystyczno-uzdrowiskowe oraz strefa podmiejska do kilkunastu kilometrów od centrum Kołobrzegu (Demilitacja... 2013, Strategia rozwoju... 2014).

Efektem końcowym przekroczenia trzeciego progu rozwojowego przez miasto Kołobrzeg będzie utworzenie (wydzielenie) KSOF, działającego już jako tzw. funkcjonalny obszar miejski lub związek międzygminny trzech gmin (miasto i gmina Kołobrzeg oraz gmina Ustronie Morskie). Ścisła integracja funkcjonalno-przestrzenna miasta i obu gmin może doprowadzić do uzyskania przez ten obszar statusu powiatu grodzkiego obejmującego pas wybrzeża Morza Bałtyckiego o łącznej długości 30 km i szerokości kilku kilometrów. Obszar ten rozciągałby się od brzegu Morza Bałtyckiego po drogę ekspresową S-6 Szczecin-Gdańsk przebiegającą wzdłuż południowych granic KSOF. Obszar ten obecnie zamieszkuje ponad 60 tys. mieszkańców, a w perspektywie do 2030 r. może to być już 70 tys. stałych mieszkańców. Turystyczno-uzdrowiskowa baza noclegowa KSOF już w roku 2013 liczyła 100 tys. miejsc noclegowych, a docelowo mogłaby osiągnąć ponad 130 tys. łóżek. Około roku 2030 KSOF Kołobrzegu poza sezonem letnim będzie mógł liczyć ponad 100 tys. mieszkańców oraz turystów i kuracjuszy, natomiast w sezonie letnim liczba ta może przekroczyć 200 tys. osób. Obecnie turystyka weekendowa osiąga wielkość między 25 a 30 tys. osób. Około 2030 r. wielkość ta mogłaby sięgnąć 50 tys. osób pod warunkiem skomunikowania z aglomeracją poznańską (linia kolejowa i droga S-11 do Poznania). Liczba ludności i turystów przebywająca w szczycie sezonu na wybrzeżu kołobrzeskim (30 km - 250 tys. osób) odpowiada ogólnej pojemności plaż o długości $30 \mathrm{~km}$ przy $10 \mathrm{~m}^{2}$ plaży przypadającej na jedną osobę wypoczywającą. 


\section{Modyfikacja cyklu życia obszaru turystycznego w oparciu o teorię progową}

Wykorzystując powyższe informacje dotyczące skali dotychczasowego rozwoju liczby ludności miasta Kołobrzeg, pojemności noclegowej drugich domów i mieszkań oraz pojemności wykorzystywanej do celów turystycznych całej oficjalnej i nieoficjalnej bazy noclegowej można stworzyć model progowy rozwoju Kołobrzegu. Niezbędna jest zatem szczegółowa delimitacja i wyznaczenie kluczowych progów rozwojowych dla Kołobrzegu.

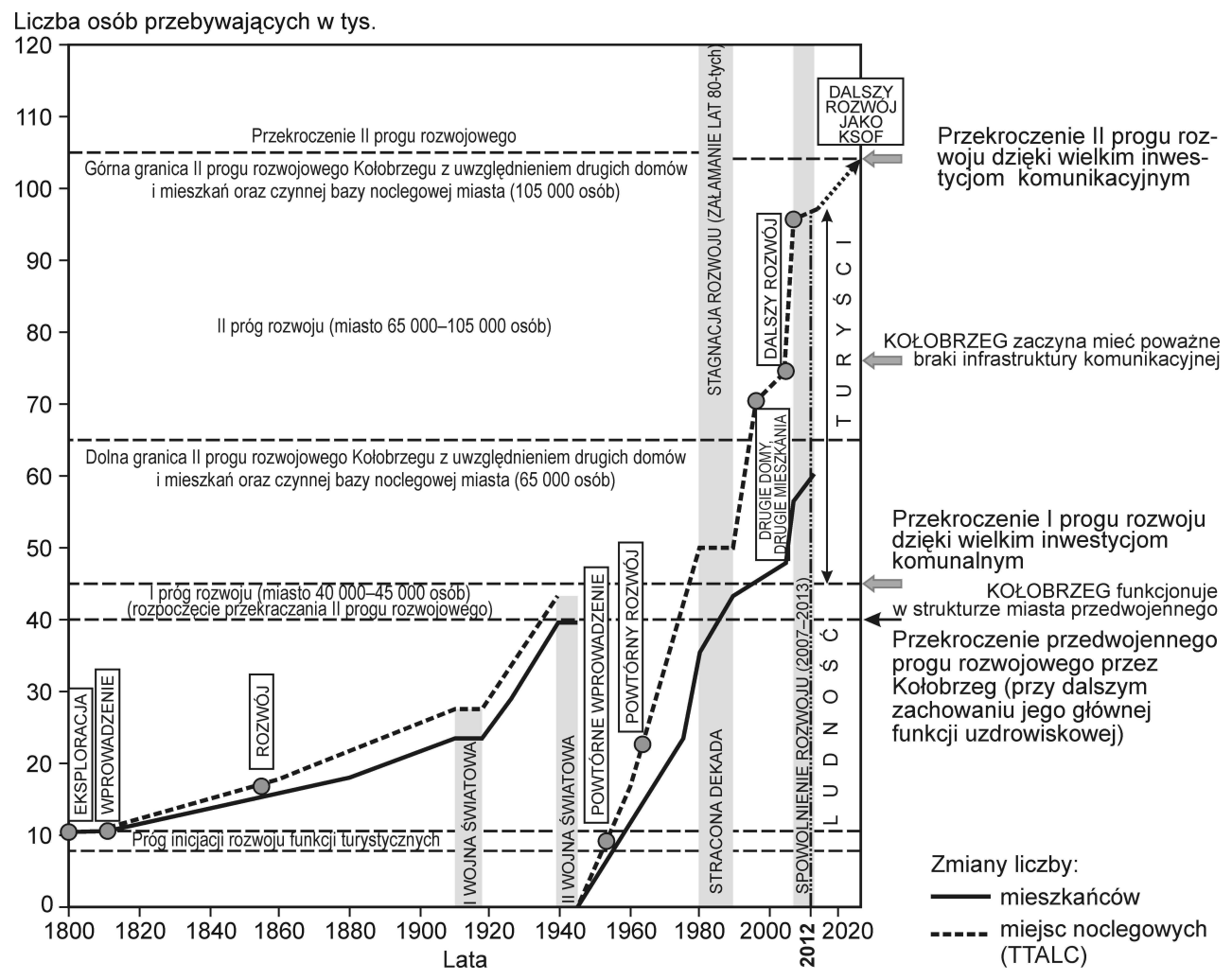

Rys. 3. Progowy cykl życia obszaru turystycznego (TTALC) dla Kołobrzegu w latach 1800-2020 uwzględniający liczbę ludności, drugie domy i mieszkania oraz bazę noclegową

Źródło: badania i opracowanie własne 
Z kolei wykorzystując założenia zmodyfikowanego cyklu życia miejscowości turystycznej według Butlera można na bazie teorii progowej B. Malisza, zmodyfikowanej przez Kozłowskiego, zbudować i zaproponować przebieg „progowego cyklu życia obszaru turystycznego" budowanego i analizowanego na przykładzie przebiegu takiego cyklu dla Kołobrzegu z uwzględnieniem skoków i spowolnień rozwojowych występujących w założeniach teorii progowej B. Malisza, łącząc potencjał demograficzny ludności danego obszaru oraz pojemność całej turystycznej i paraturystycznej bazy noclegowej (rys. 3, 4).

Skala przebiegu dotychczasowych procesów przemian przestrzennych i funkcjonalnych, jakie dokonały się w Kołobrzegu przy braku innych porównywalnych obszarów turystycznych, pozwalają na podjęcie próby modyfikacji klasycznego cyklu życia obszaru turystycznego R.W. Butlera poprzez wprowadzenie elementów progowych, związanych ściśle z teorią progową B. Malisza (rys. 4), tworząc teoretyczne założenia dla progowego cyklu życia obszaru turystycznego (TTALC).

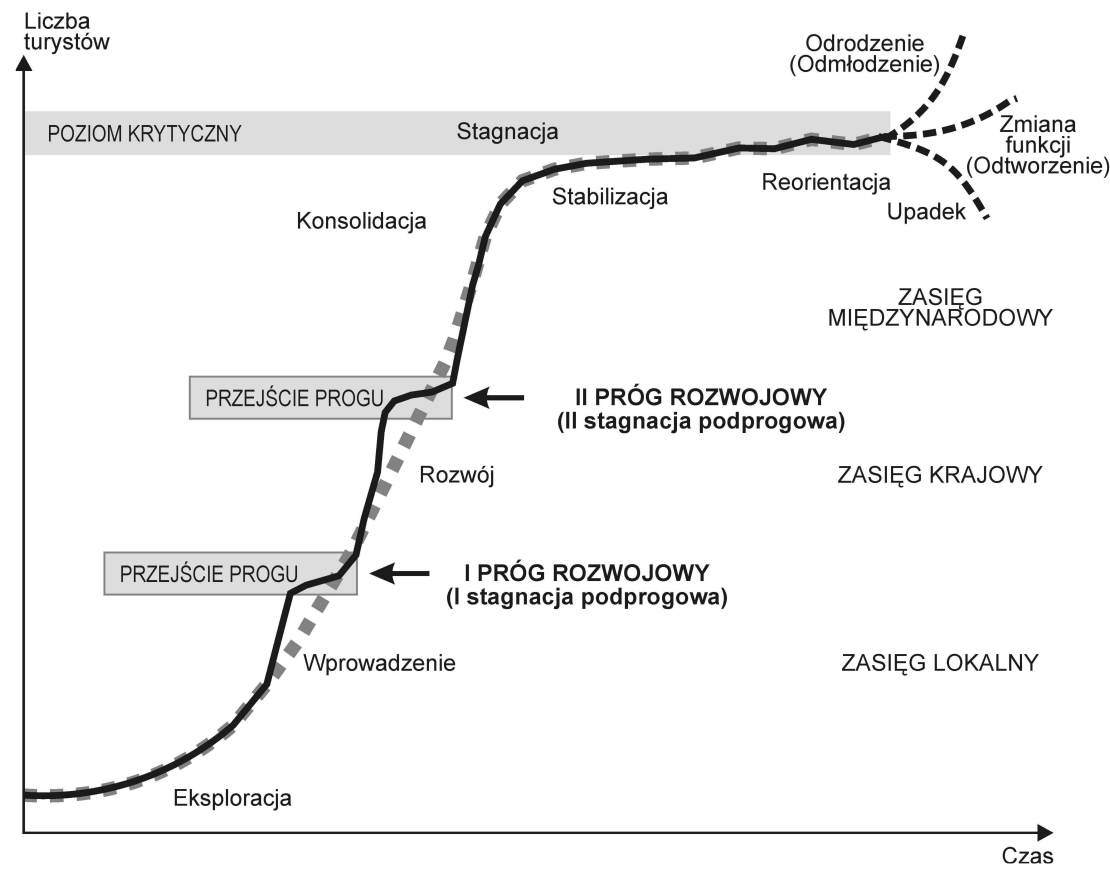

Rys. 4. Klasyczny zmodyfikowany progowy cykl życia obszaru turystycznego według R.W. Butlera z późniejszymi zmianami wprowadzanymi przez innych autorów Źródło: opracowanie własne na podstawie R.W. BUTLER (2011, s. 33) 
Bazując na teoretycznym TTALC w rozwoju Kołobrzegu można wyróżnić:

- I powojenny okres intensywnego rozwoju (1958-1979), (etap odbudowy Kołobrzegu);

- I powojenny okres spowolnienia rozwoju (1980-1989), przekraczanie pierwszego progu rozwoju;

- II powojenny okres intensywnego rozwoju (1990-2007), pokonanie pierwszego progu rozwoju;

- II powojenny okres spowolnienia rozwoju (2008-2010), przekraczanie drugiego progu rozwoju;

- wejście w trzeci powojenny okres intensywnego rozwoju (od 2011), utworzenie - KSOF.

Taki skokowy progowy przebieg cyklu życia dla obszaru - miejscowości turystycznej (TTALC) może być wyłącznie efektem bardzo długiego okresu życia, jaki można obserwować w przypadku co najmniej kilkudziesięciu lat rozwoju funkcji turystycznych. Mamy wówczas do czynienia z cyklicznym procesem odnawiania (odmładzania) obszaru turystycznego. W przypadku Kołobrzegu przebieg drugiego powojennego cyklu życia obszaru turystycznego świadczy co najmniej o jednokrotnym, a być może już o dwukrotnym przejściu przez cały cykl TALC z odmłodzeniem (odrodzeniem - rewitalizacją) funkcji turystycznych badanego obszaru turystycznego.

\section{Podsumowanie}

Progi rozwojowe wskazane przez autora $\mathrm{w}$ niniejszym opracowaniu na przykładzie rozwoju największego w kraju nadmorskiego centrum turystyki uzdrowiskowo-wypoczynkowej, jakim jest obecnie Kołobrzeg wraz z otaczającymi go kilkoma sąsiednimi miejscowościami wypoczynkowymi, stanowią wyraźne i widoczne w przestrzeni elementy (etapy) rozwoju obszaru turystycznego. Miasto Kołobrzeg i opierający się na nim Kołobrzeski Subregionalny Obszar Funkcjonalny (KSOF), rozwijający się w oparciu o główne funkcje uzdrowiskowo-turystyczne, uzupełniane przez gospodarkę morską, usługi, budownictwo i transport, może stanowić wyjątkowy w skali kraju przypadek przemian i procesów społeczno-gospodarczych, przestrzenno-funkcjonalnych i kolonizacyjno-urbanizacyjnych $w$ ramach nadmorskich obszarów turystycznych. 
Nagromadzony w okresie Polski Ludowej kapitał społeczny i gospodarczy, eksplozja przedsiębiorczości lat 90. XX w., połączona z korzystnymi dla przyszłości Kołobrzegu przemianami społecznymi i własnościowymi realizowanymi w oparciu o własne zasoby miasta i jego mieszkańców oraz praktycznie nieograniczona swoboda rozwoju funkcji uzdrowiskowo-turystycznych $w$ ramach sprzyjających zdarzeń makroekonomicznych i inwestycyjno-decyzyjnych, pozwoliły na jedyny w swoim rodzaju rozwój wielkiego centrum uzdrowiskowo-turystycznego na polskim wybrzeżu Morza Bałtyckiego.

Poprawa dostępności komunikacyjnej miasta Kołobrzeg oraz opierającego się na nim KSOF, poprzez modernizację, rozbudowę i budowę dróg ekspresowych S-6 i S-11, uruchomienie sezonowych szybkich połączeń kolejowych, działalność regionalnego lotniska sportowo-turystycznego w Bagiczu k. Kołobrzegu, bezpośredniego połączenia kolejowego z lotniskiem międzynarodowym w Goleniowe, uruchomieniu linii promowej i zakończeniu budowy największej w kraju mariny mogą być docelowo istotnymi czynnikami (poprzez poprawę dostępności komunikacyjnej) umożliwiającymi osiągnięcie przez Kołobrzeg statusu uzdrowiska rangi europejskiej i kluczowego centrum turystycznego kraju, obok Warszawy, Krakowa, Gdańska, Wrocławia i Poznania.

Klasyczny przebieg cyklu życia obszaru turystycznego (TALC) powinien być analizowany na przykładach kilkudziesięciu lat nieprzerwanego rozwoju obszaru turystycznego. Jednym z takich przykładów bardzo znacznego wydłużenia czasu przebiegu TALC jest, wspomniany już, opisywany w literaturze przypadek chorwackiego uzdrowiska Opatija (była Jugosławia), gdzie wystąpiły trzy cykle TALC, które po połączeniu ze sobą tworzyły jeden wielki cykl TALC. W tym przypadku przerwy dotyczyły I i II wojny światowej i okresu wojen bałkańskich w połączeniu z transformacją ustrojową i wystąpił tu jeden bardzo długi pełny cykl, trwający co najmniej 50 lat, przy czym dodatkowo pojawiła się realizowana planowo transformacja gospodarcza (restrukturyzacja, przemiana, odnowa) całości funkcji turystycznych i bazy noclegowej. Dodatkowym warunkiem jest także skala przemian obszaru turystycznego oraz wielkość odnotowywanej w nim bazy noclegowej i ruchu turystycznego, a także duża liczba ludności. Wskazanie do badań tylko wystarczająco dużych obszarów turystycznych pod względem przestrzennym, historycznym i społeczno-gospodarczym w znaczący sposób ogranicza możliwości analiz małych obszarów (ośrodków) turystycznych, na których skala dokonywanych przemian przestrzennych, funkcjonalnych 
i wielkościowych jest zbyt mała, by zaznaczyły się wyraźne zmiany biegu cyklu życia obszaru turystycznego. Powinien to być obszar o istotnym potencjale atrakcji turystycznych i ruchu turystycznego, dużym potencjale demograficznym (liczbie mieszkańców - kapitał społeczno-gospodarczy) oraz znacznej bazie noclegowej o charakterze turystycznym i paraturystycznym. Badany obszar powinien także mieć duże znaczenie gospodarcze, by wygenerować endogeniczne siły do przekroczenia progów rozwojowych oraz do przesunięcia tzw. krytycznego przedziału pojemności turystycznej - czyli teoretycznego, a także faktycznego wydłużenia możliwości kontynuacji cyklu życia badanego obszaru turystycznego w dalszej przyszłości.

W celu przeprowadzenia dokładnych badań przebiegu TALC oraz wprowadzania jego modyfikacji konieczne jest odnalezienie co najmniej kilku przykładów obszarów turystycznych spełniających następujące parametry funkcjonalne:

- liczba ludności głównego miasta (centrum ruchu turystycznego) na którym opiera się FOM (lub strefy podmiejskiej), powinna liczyć około 50 tys. osób;

- absolutna specjalizacja miasta w określonym typie funkcji turystycznej, np. funkcja turystyki uzdrowiskowej (wskaźniki działalności uzdrowiskowej na najwyższym poziomie w skali danego kraju), w tym dominujący w skali kraju odsetek kuracjuszy zagranicznych, ewentualnie funkcja turystyki górskiej, wypoczynkowej;

- ogólna pojemność turystyczna bazy noclegowej powinna być mniejsza lub zbliżona do dopuszczalnych wielkości chłonności turystycznej badanego obszaru;

- pojemność bazy noclegowej powinna być zbliżona lub większa od liczby ludności;

- powinien mieć miejsce wysoki poziom rozwoju innych paraturystycznych oraz towarzyszących funkcji miejskich (usługi, handel, gastronomia, komunikacja i transport, np. port morski) z zapewnieniem dobrej dostępności komunikacyjnej;

- powinien cechować się korzystnymi wskaźnikami gospodarczymi (np. niskie bezrobocie, bardzo wysoka liczba podmiotów gospodarczych na 1000 mieszkańców, wysokie własne dochody budżetowe, niski poziom zadłużenia itp.), co zwykle potwierdza wysoki poziom funkcji turystycznych i wywiera korzystny wpływ turystyki na gospodarkę (kontynuacja cyklu życia a nie wejście w fazę stagnacji lub upadku); 
- powinna wystąpić faktyczna realizacja lub możliwość realizacji inwestycji pozwalająca na kolejne przesunięcia tzw. krytycznego przedziału pojemności turystycznej, dzięki czemu możliwa będzie kontynuacja dalszego rozwoju przestrzeni turystycznej i oddalanie ryzyka upadku obszaru turystycznego w wyniku pogorszenia warunków funkcjonowania przestrzeni turystycznej.

W Europie jest niewiele obszarów turystycznych spełniających wszystkie wspomniane wyżej kryteria. Uzdrowisko Kołobrzeg wraz z otaczającym je miejskim obszarem funkcjonalnym spełnia powyższe kryteria i wykazuje cechy, które umożliwiają pełną analizę przebiegu teoretycznego modelu TALC R.W. Butlera wraz z jego licznymi modyfikacjami, przy zachowaniu zdolności do dalszego kontynuowania cyklu życia obszaru turystycznego. Przykład miasta uzdrowiska Kołobrzeg pozwala zaproponować kolejną autorską modyfikację TALC $\mathrm{w}$ oparciu o progi rozwojowe, przy czym należy mieć świadomość, że wprowadzenie progów w przebieg TALC wymaga kontynuacji badań (MIEDZIŃSKI 2013c) i weryfikacji wyników na innych przykładach przebiegu cyklu życia obszarów turystycznych.

\section{LITERATURA}

AgarWaL S., 2006, Coastal Resort Restructuring and the TALC Model, [w:] R.W. Butler (ed.) The Tourist Area Life Cycle. Conceptual and Theoretical Issues, Clevedon, Channel View Publications, s. 201-218.

ButLER R.W., 1980, The Concept of a Tourist Area Cycle of Evolution: Implications for Managment of Resources, "The Canadian Geographer", 24, s. 5-12.

ButLer R.W., 2011, Tourist Area Life Cycle, "Contemporary Tourist Reviews”, Oxford, OX3 9TJ.

CORAK S., 2006, The modification of the tourism area life cycle model of Re (inventing) a destination: the case of the Opatija Riviera, Croatia, [w:] R.W. Butler (red.), The tourist area life cycle, vol. 1: Applicacions and Modifications Channel Viev Publications, Cleventon, Buffalo, Toronto, s. 271-287.

Demilitacja Kołobrzeskiego Subregionalnego Obszaru Funkcjonalnego (KSOF) i opracowanie strategii jego rozwoju; przetarg nieograniczony o wartości powyżej 14000 euro - ogłoszenie zostało wysłane i opublikowane w Biuletynie Zamówień Publicznych w dniu 29.10.2013 r. pod numerem 439770-2013.

JOHNSTON C.S., 2001, Shoring the Foundations of the Destination Life Cycle Model, part 1: Ontological and Epistemological Considerations Tourism Geographies, 3 (1), s. 2-28.

KOWALCZYK A., 2001, Geografia hotelarstwa, Wyd. Uniwersytetu Łódzkiego, Łódź.

KOZŁOWSKI J., 1974, Analiza progowa, Prace Instytutu Kształtowania Środowiska, PWN, Warszawa.

KROCZYŃSKI H., 2000, Kronika Kołobrzegu, Wyd. Le Petit Cafe, Kołobrzeg. 
MALISZ B., 1971, Metoda analizy progowej w zastosowaniu do planowania miast i regionów, [w:] B. Malisz, J. Żurkowski (red.), Metoda analizy progowej, Studia KPZK PAN, 34, Warszawa, s. 27-47.

MIEDZIŃSKI M., 2009, Rozwój przestrzenny uzdrowiska Kołobrzeg od 1830 do 2009 roku oraz przemiany jego bazy noclegowej w latach 1989-2009, [w:] E. Wiśniewski (red.), W trosce o przyszłość kołobrzeskiego uzdrowiska - międzynarodowe forum uzdrowiskowe, Regionalne Stowarzyszenie Turystyczno-Uzdrowiskowe, Kołobrzeg, Intro-Druk, Koszalin, s. 124-137.

MIEDZIŃSKI M., 2011, Kołobrzeg jako centrum turystyki uzdrowiskowo-wypoczynkowej po 20 latach przemian ustrojowych (1989-2009), [w:] B. Włodarczyk, B. Krakowiak, J. Latosińska (red.), Turystyka polska w latach 1989-2009, ser. „Warsztaty z Geografii Turyzmu”, Wyd. Uniwersytetu Łódzkiego, Łódź, s. 115-126.

MiEDZIŃSKI M., 2012, Miasto Kołobrzeg wiodącym uzdrowiskiem Polski i jednym z centrów turystycznych kraju, [w:] E. Rydz (red.), Ekonomiczne i organizacyjne aspekty funkcjonowania polskich uzdrowisk, Wyd. Akademii Pomorskiej, Słupsk, s. 139-150.

MIEDZIŃSKI M., 2013a, Możliwości rozwojowe portu morskiego w Kołobrzegu po zakończonej przebudowie wejścia oraz trwajacej poprawie dostępności portu od strony lądu, [w:] Regiony nadmorskie, Wyd. Uniwersytetu Gdańskiego, Gdańsk, s. 66-77.

MiEDZIŃSKI M., 2013b, Możliwości zmiany granic administracyjnych miasta Kołobrzeg w kontekście jego rozwoju przestrzennego i funkcjonalnego, Słupskie Prace Geograficzne, Słupsk, s. 99-108.

MiEDZIŃSKI M., 2013c, Uzdrowisko Kotobrzeg w świetle zmodyfikowanego cyklu życia obszaru turystycznego R.W. Butlera oraz teorii progowej B. Malisza, [w:] Turystyka uzdrowiskowa w gospodarce regionów, Zeszyty Naukowe, Ekonomiczne Problemy Turystyki, Wyd. Naukowe Uniwersytetu Szczecińskiego, RSTU, Kołobrzeg, s. 209-224.

Strategia rozwoju Nadmorskiego Obszaru Funkcjonalnego obejmujacego gmine miasto Kołobrzeg, gminę Kołobrzeg oraz gminę Ustronie Morskie, 30 I 2014 r., Instytut Badawczy IPC, Wrocław, 2014, ss. 115.

SZROMEK R.A., 2010, Cykliczność rozwoju uzdrowisk na przykładzie uzdrowisk polskich, [w:] A.R. Szromek (red.), Uzdrowiska $i$ ich znaczenie w gospodarce turystycznej, Proksenia, Kraków, s. $17-40$. 